\title{
How States Exerted Power to Create the Millennium Development Goals and How this Shaped the Global Health Agenda: Lessons for the Sustainable Development Goals and the Future of Global Health
}

\author{
Robert Marten \\ Global Health and Development, London School of Hygiene and Tropical Medicine, 5-17 \\ Tavistock Pl, Kings Cross, London WC1H 9SH, UK, London, UK. \\ Robert.Marten@lshtm.ac.uk @martenrobert
}

\begin{abstract}
:
Since 2000, the eight Millennium Development Goals (MDGs) provided the framework for global development efforts transforming the field now known as global health. The MDGs both reflected and contributed to shaping a normative global health agenda. In the field of global health, the role of the state is largely considered to have diminished; however, this paper reasserts states as actors in the conceptualization and institutionalization of the MDGs, and illustrates how states exerted power and engaged in the MDG process. States not only sanctioned the MDGs through their heads of states endorsing the Millennium Declaration, but also acted more subtly behind the scenes supporting, enabling, and/or leveraging other actors, institutions and processes to conceptualize and legitimize the MDGs. Appreciating the MDGs' role in the conceptualization of global health is particularly relevant as the world transitions to the MDGs' successor, the Sustainable Development Goals (SDGs). The SDGs' influence, impact and importance remains to be seen; however, to understand the future of global health and how actors, particularly states, can engage to shape the field, a deeper sense of the MDGs' legacy and how actors engaged in the past is helpful.
\end{abstract}

Keywords: Power, Millennium Development Goals, Global Health, Global Health Governance, Global Health Policy

Word Count: 7836 words 


\section{Introduction}

From 2000-2015, the eight Millennium Development Goals (MDGs) provided the framework for global development efforts. The MDGs shaped billions of dollars of investment, and impacted the lives of many. Advocates contend they invigorated institutions, stimulated research communities, inspired civil society movements and galvanized politicians and citizens (McArthur, 2013). Scholars argue the MDGs represented a new 'super norm' dominating the global development agenda (Fukuda-Parr \& Hulme, 2011). Three out of the eight goals related directly to health and the other five goals focused on critical determinants of health. The MDGs' influence was pivotal to creating a normative global health agenda, which largely continues to shape the global health agenda today. Appreciating the MDGs' role and legacy in the conceptualization of global health is particularly relevant as the world transitions from the MDGs to the Sustainable Development Goals (SDGs). The SDGs' influence, impact and importance remains to be seen; however, to understand global health now and in the future and assess how actors, like states, can engage to shape the field, a deeper sense of the MDGs' origins and of how actors engaged in the past is instructive.

Defining and determining what is and what is not considered part of the global health agenda remains disputed. There is no single global health agenda (Fried et al., 2010; McInnes \& Lee, 2012). Yet how global health is defined and understood shapes which health challenges are considered (Frenk, Gómez-Dantés, \& Moon, 2014). The definition impacts the design of how funds are raised and eventually disbursed. It influences discourse and how policymakers consider issues. It determines the education of students and future policymakers. The global health agenda can also contribute to the creation of new global health institutions like the Global Fund or GAVI, the Vaccine Alliance. In other words, the conceptualization of global health exerts power by determining the global health agenda. As recently argued, 'power is exercised everywhere in global health although its presence may be more apparent in some instances than others' (Shiffman, 2014).

While the tremendous normative power of the MDGs is increasingly recognized, there is limited analysis considering the explicit role of sovereign states as actors within the process to create the MDGs. Existing literature highlights the important role of civil society and non-governmental actors (Brinkerhoff, Smith, \& Teegen, 2007), "norm champions" (Fukuda-Parr \& Hulme, 2011) and "well-placed individuals within the UN" (Miskimmon, O'Loughlin, \& Roselle, 2017); however, to better identify both the origins and future of global health as a field of policy action, it is necessary to reconsider how state actors engaged in this process to create the MDGs. What were states' roles in the policymaking process to create the MDGs? Why and how did states engage to shape and influence the process?

Despite broad recognition of the MDGs' and their role in development, their relationship to the rise of the field of global health is less explicitly acknowledged. Part of this could be the tension between the normative aspiration of global health to transcend states and national borders with the reality of the MDGs and global health institutions still operating within an UN-state system. This could help explain why seminal articles assessing the transition from international to global health do not even mention the MDGs (Brown, Cueto, \& Fee, 2006). This is somewhat paradoxical given that the MDGs had a strong health focus and that the emergence of global health in the late 1990s and early 2000s broadly coincided with the United Nations' (UN) Millennium Declaration. The MDGs also built on previous advocacy efforts. For example, the MDG 4 on Child Mortality built on the experience of the child-survival revolution in the 1990s (Díaz-Martínez \& Gibbons, 2014). 
The MDGs also matter for global health as issues not included within the MDG agenda, like non-communicable diseases (NCDs), received reduced interest, attention and resources within the field of global health. Conversely issues included in the MDGs, like HIV/AIDS, gained disproportionate and distortionary attention possibly displacing other health spending (Shiffman, 2008). Some experts argued that the quantification of the MDGs and their targets led to "simplification, reification and abstraction" which contributed to redefining some of the priorities (Fukuda-Parr et al, 2014). By 2014, roughly $\$ 23$ billion out of a total of $\$ 36$ billion of Development Assistance for Health (DAH) was directed towards MDGs Four, Five, and Six whereas only $\$ 611$ million was directed towards NCDs (Dieleman et al, 2015). Moreover, since 1990 DAH associated with the MDGs increased more than any other areas (Dieleman et al., 2016). While this was not necessarily the case for every goal and target within the MDGs, it was the case that if a health challenge was not a MDG goal or target, it was more difficult to raise support and awareness for this issue in the MDG era. Anticipating this situation, UNAIDS' Director Peter Piot fiercely advocated for HIV/AIDS to be included in the MDGs (Piot, 2013).

At their inception, the MDGs caused rigorous debate amongst academics, civil society and policymakers around the world with one early critic calling them a "Major Distraction Gimmick" (Antrobus, 2005) being forced upon developing countries by the triad of the United States, Europe and Japan (Samin, 2006). Yet some of these early critiques were eventually forgotten or ignored considering the power of the MDGs' supporters, and as the MDGs became more entrenched as development policy. Indeed, a recent review (Fehling, Nelson, \& Venkatapuram, 2013) found that "only 15 percent of MDG-related publications expressed concerns with the MDGs and only one-third of these discussed intrinsic limitations. From this more narrow literature, the review considers MDGs' limitations in terms of the development process (Samin, 2006), structure (Saith, 2006), content (Easterly, 2008) as well as implementation and enforcement (AbouZahr \& Boerma, 2010).

Despite these critiques, an early Millennium Project report declared, that the MDGS were "the most broadly supported, comprehensive, and specific poverty reduction targets the world has ever established"(UN Millennium Project, 2005). A UN MDGs final report defined them as the "most successful anti-poverty movement in history" (United Nations, 2015). The MDGs reflected a departure from the 1980s Washington consensus development to a more people-centered or human development in the 1990s expressed during a series of UN conferences on development issues (Wilkinson \& Hulme, 2012). Accordingly, as experts noted the MDGs arguably "created a new narrative of international development centered on global poverty" with the MDGs "the legitimized framework for defining what this means" and the "reference point around which international debates about development revolve" (Wilkinson \& Hulme, 2012).

More specifically within global health, the MDGs remained contested. The MDGs represent the apex of an extremely "vertical" (focused on specific diseases, like HIV/AIDS or malaria as opposed to a horizontal approach focused on health systems) approach to health interventions. The three health-specific MDGs focused on a small number of vertical interventions to combat specific diseases and maternal and child mortality as the most effective approach to reach the goals. By 2008, advocates noted, "[t]he potentially destructive polarization" between vertical and horizontal approaches (Ooms et al, 2008). The Maximizing Positive Synergies initiative (detailed in Section Two below) helped diffuse this tension leading to greater attention to health systems and a more integrated approach 
within health. But the MDGs remained the dominant policy doctrine. In fact, it appears the MDGs dominated the agenda so much so that they even eventually contributed towards a more horizontal approach. One analysis found that "critical factors behind the recent burst of attention [to health systems] include fears among global health actors that health systems problems threaten the achievement of the health-related MDGs" (Hafner \& Shiffman, 2013). ${ }^{1}$ Within global health, the MDGs shaped priorities and investments. The MDGs both reflected an emerging definition of global health, and contributed to advancing this conceptualization. They exerted power and facilitated by the UN and civil society partners were enacted through and within nation states.

The role of power as a concept and framework for assessing how global health policy is determined is often overlooked. As Erasmus and Gilson argued, 'power, a concept at the heart of the health policy process, is surprisingly rarely explicitly considered in the health policy implementation literature' (Erasmus \& Gilson, 2008). Frameworks for understanding power remain contested and empirical evidence for applying these frameworks is often lacking. Given the importance of the MDGs in shaping the global health agenda, understanding how states engaged to create the MDGs could help illustrate how actors exert power in global health and hence inform how actors both engaged in the conceptualization of the SDGs and might engage with their implementation shaping the future of global health.

Based on published literature and unpublished policy materials, this paper focuses on reconsidering the role of states as critical actors in both the conceptualization and institutionalization of the MDGs. While state engagement in the recent SDG process was more visible and legible, some states, contrary to common perceptions, were also critical actors in the creation of the MDGs. States as actors within global health are sometimes overshadowed by the attention given to the proliferation of new actors, like public-private partnerships, civil society organizations or philanthropies (Ricci, 2009). In the case of the MDGs, states not only sanctioned the MDGs through head of states endorsing the Millennium Declaration, but also acted more subtly behind the scenes supporting, enabling (sometimes by not blocking), and/or leveraging other actors, institutions and processes to conceptualize the MDGs.

This paper considers why, and how, states exerted power and engaged in the MDG process. This paper starts by presenting an overview of different potential frameworks for analyzing the role of states in the creation of the MDGs, and selects the Barnett and Duvall framework (considering compulsory, productive, structural and institutional power) for analysis (Barnett \& Duvall, 2005a). Second, this paper applies this framework describing and analyzing how states exerted power in the creation and institutionalization of the MDGs in three distinct phases (2000-2005; 2005-2010; and 2010-2015) in relation to the emergence of the field of global health. Finally, it considers and discusses the implications of this analysis for the recent transition from the MDGs to the SDGS, and what this might mean for the implementation of the SDGs and the future of global health.

\section{Section One: Power as a new framework for understanding global health}

\footnotetext{
${ }^{1}$ Of course, defining health systems and how to best strengthen them to help achieve the MDGs is also heavily disputed. Health systems frameworks are influenced by their authors (van Olmen et al, 2012) as well as new global health institutions many of which were funded and influenced by the creation of the Bill and Melinda Gates Foundation (Storeng, 2014) in the late 1990s (Birn, 2014) and their focus on vertical and technocratic approaches to health (McCoy et al, 2009).
} 
Power is a central concept in social sciences, but its meaning and application is heavily contested. Scholars disagree about sources of power, the role of power and how actors exert power. Indeed, one international relations scholar describes the concept of power as one of the 'most troublesome in the field' and argues that 'the number and variety of definitions should be an embarrassment to political scientists' (Gilpin, 1975, 1983). Traditionally scholars have seen power conceptually defined by an actor or state's resources like armies or navies and populations or territories. But in the second half of the twentieth century, this approach evolved to consider 'relational power', in other words, how actors, individually or in groups, related to each other and affected or influenced others' behavior. Beyond this, many debates and different approaches in terms of how to exert, frame, measure or understand power remain. Yet there is a consensus on the importance of understanding power and the lack of knowledge on how power functions (Baldwin, 2016). There is a similar, but slightly less mature, state of affairs in the global health literature.

There is an increasing recognition of the concept of power in global health, but discussions are still nascent (Shiffman, 2014). Similar to international relations, power in health remains associated with possession of or access to material resources like financing or medical equipment or drugs; however, there is an emergent recognition of ideas (McDougall, 2016), networks (Shiffman, 2016), expertise and information (Shearer et al, 2016) as potential sources of power. This is critical for global health as many consider health a policy process dictated by technical choices instead of recognizing health as a profoundly political space in which various priorities and policies are fiercely contested and ideas, networks, expertise and information are deployed to advance competing approaches (Shiffman, 2014).

From the international relations literature, there are a few different frameworks for understanding how power is exerted, which could be considered for global health. One of the simplest and perhaps most intuitive ways to illustrate how power is exerted is to compare hard and soft forms of power. Robert Dahl's famous formulation of hard power is the ability of A to force B to do something it would not otherwise do (usually deploying military or economic resources), and Joseph Nye's conceptualization of soft power attracts or co-opts actors and persuades actors without the use of coercive force. In global health, Brazil's influential role in advancing its political values on the negotiation of the Framework Convention on Tobacco Control is often cited as an example of soft power (Lee, Chagas, \& Novotny, 2010). More recently, others argued that to best advance interests, actors should seek to combine both hard and soft power to create smart power (Nossel, 2004). For example, one could consider American efforts on HIV/AIDS like PEPFAR advancing American interests in geopolitically strategic countries backed up with financial resources as an example of smart power.

A similar framework from sociology is Lukes' three faces of power (Lukes, 2004). The first face of power is the ability of one actor to force another actor to do something they initially did not want to do, ie hard power. The second face of power is considered agenda setting and framing; powerful actors can control the agenda and determine who sits at the table and which issues are considered to be or not be on the agenda (Bachrach \& Baratz, 1962). The third face of power is the ability to control an actor's thoughts. For example, one actor might be able to shape another actor's initial interests. These three faces of power could be summarized as overt, covert or latent forms of power. This three faces of power framework was briefly applied recently to examine the process to create the SDGs (Buse \& 
Hawkes, 2014). While the hard, soft, smart power framework is helpful for examining state actions at the international level, Lukes' faces of power is most helpful for assessing the negotiation of policy processes as the framework illustrates how actors can shape the agenda by putting or removing issues from consideration (the second face of power) and/or controlling the terms or framework for conceptualizing issues (the third face of power).

Building on Lukes, global governance scholars Barnett and Duvall present a broader framework for understanding power, which is insightful for understanding how states negotiate policy processes. They consider power to be about relationships, and define it 'as the production, in and through social relations, of effects that shape the capacities of actors to determine their circumstances and fate' (Barnett \& Duvall, 2005b). They differentiate between four forms of power-compulsory power (such as use of military or economic force), institutional power (such as how international institutions are designed to favor one actor over another), structural power (the overall constitution or framework of actor and their roles) or productive power (control over the possession and distribution of resources) (Barnett \& Duvall, 2005a). For global health, one could think of a donor using funding to exert compulsory power; a well-positioned state leveraging a multilateral agency to exert institutional power; a prestigious university or NGO positioning its staff as experts to provide technical policy support as exerting structural power; and a UN agency or a private-sector actor advancing and promoting a particular agenda or approach to addressing health challenges as an exertion of productive power.

Given the breadth of Barnett and Duvall's framework to distinguish between different forms of power, particularly to identify and illuminate ways in which power is exerted in ways usually unseen or unrecognized, the next section below applies this framework to analyze and illustrate state engagement in the creation of the MDGs.

\section{Section Two: State Power and the creation of the MDGs}

\section{Phase One 2000-2005: Conceptualization and Campaign}

One year after the unanimous endorsement of the 2000 Millennium Declaration during the Millennium Summit with 149 heads of states and governments (the largest ever such gathering), UN Secretary General Kofi Annan submitted a report to the General Assembly entitled, a Roadmap towards the Implementation of the Millennium Declaration (UN Secretary-General, 2001). This report was adopted by the General Assembly, and recommended it be considered a 'useful guide' for operationalizing the Declaration. An annex to this report included the framework for the Millennium Development Goals (MDGs): eight goals, eighteen targets and forty-eight indicators. This MDG resolution, based on the Declaration approved and endorsed by heads of states and governments, would ultimately be leveraged by the United Kingdom and other OECD states to exert tremendous structural, institutional and productive power.

Recognizing the role of states in shaping policy is not to dismiss the role of message and norm entrepreneurs as well as elite technocrats highlighted elsewhere (Hulme \& Fukuda-Parr, 2009). Instead it is meant to reconsider these individuals' roles as enabled by states exerting structural, institutional and productive power. For example, three of the Security Council's five permanent five seats are held by OECD-member states, the United States, France and the United Kingdom. These states have veto or structural power over the appointment of the Secretary-General, and thus have influence over the Secretary-General's 
office; a similar situation is true for other UN agencies and other parts of UN institutions. States use this structural power to install their nationals into key positions shaping policies within these institutions and establishing critical personal connections. States also leverage institutional power through the OECD and World Bank as well as the UN.

Following the Millennium Declaration and in coordination with the World Bank and OECD, a United Nations' interagency expert group (IAEG) both reflected institutional power and exerted productive power. Co-chaired by a special adviser in the Secretary General's office (Michael Doyle) and director (Jan Vandemoortele) in the United Nations Development Programme (UNDP) and with participants from both the Bank and the OECD, this group, sanctioned by OECD states, led the process to draft what became the eight MDGs (FukudaParr \& Hulme, 2011). The Goals were taken almost verbatim from the Millennium Declaration, which helped to legitimize them as the Declaration had been approved by Heads of State. The eight MDGs consolidated and built upon the so-called International Development Goals (IDGs) created at the Paris-based Organization for Economic Cooperation and Development (OECD). In fact, MDGs 1 through 7 were extremely similar to the IDGs. The biggest difference between the IDGs and the MDGs was Goal 8 on partnership, which was the result of political consultation and compromise following the Millennium Declaration, most notably between the G77 Member States who believed the Goal did not go far enough and the United States which believed it went too far (McArthur, 2014).

The IDGs came from a working group of national Ministers of Development which met in the Development Assistance Committee (DAC) at the OECD to produce a 1996 report, Shaping the $21^{\text {st }}$ Century. This report selectively included goals and language from UN conferences in the 1990s. These IDGs were endorsed in June 2000 by the UN, OECD, World Bank and the IMF (A Better World for All, 2000), but the IDGs' productive power had little buy-in or support from developing countries. In fact, the IDGs engendered deep critique on a number of levels from developing countries and civil society. The IDGs had been promoted by the United Kingdom, which led an informal group, the so-called Utstein Group, of female Development Ministers from the Netherlands, Germany and Norway, which sought to use the IDGs as their overarching framework for development and align their aid efforts to leverage their impact (Hulme, 2009). This would also be an exertion of compulsory power by developed states coercing developing states to adopt policy guidance in exchange for development assistance. The strong commitment from the United Kingdom was championed by Clare Short, who had recently come to lead DFID as part of the 1997-elected New Labour government (Hulme, 2007). As part of a broader shift in development thinking and fortuitous timing with the Millennium Summit, the UK and the other states' institutional power within the World Bank and the IMF advanced the productive power of the IDGs eventually leveraging the UN to reframe and rebrand the IDGs as MDGs through negotiation with the addition of Goal 8 on partnership to overcome resistance from developing country states.

Other than the goal on global partnership, the IDGs were largely the same as the MDGs on health except one key difference. Both lists of goals contained maternal and child mortality (although they were one goal in the IDGs and two goals in the MDGs), but the IDGs included a goal on reproductive health services, whereas the MDGs had a goal on HIV/AIDS. The removal or blocking of reproductive rights as part of the MDGs was the result of the socalled 'unholy alliance' between the Vatican and Sudan, along with Libya and Iran, which then leveraged the G-77, a large and powerful bloc of countries within the UN General Assembly, and also took advantage of a recently-elected conservative US government (the 
administration of President George W. Bush), which was initially disinterested in the MDGs (Hulme, 2010). In this case, the Vatican State exploited institutional or structural power, joining some members of the G-77, to block a potential MDG on reproductive health. This alliance later broke down in 2005, and reproductive health was included as a target for maternal health. HIV/AIDS was included as a MDG following vigorous lobbying from HIV/AIDS activists led by UNAIDS Director Peter Piot from Belgium.

UNDP, newly led by former World Bank Vice President (Mark Malloch Brown), spearheaded the development of a strategy to exert institutional power and advocate for MDG implementation. These efforts ultimately included a Millennium Project and a Millennium Campaign to raise attention, financing and support to advance progress. UNDP worked with governments to embed the MDGs within national policy processes and monitor progress. The 2002 Monterrey Finance for Development Conference focused on financing the MDGs (Fukuda-Parr \& Hulme, 2011). Despite these efforts, national commitment to the MDGs at this point was limited, and in the early stages the MDGs provoked robust critiques.

Hulme (2009) distinguishes between various schools of critique classifying them as "high modernists, who take [the MDGs] at face value and are optimistic that they are a blueprint for the transformation of the human condition (Sachs, 2005); the strategic realists, who don't believe the MDGs are a blueprint for action but believe they are essential to stretch ambitions and mobilise political commitment and public support (Fukuda-Parr, 2008); the critics, who see them as well-intentioned but poorly thought through - distracting attention from more appropriate targets (or non-targets) and more effective policies and actions (Clemens et al, 2007; Easterly, 2006); through to the radical critics, who view them as a conspiracy obscuring the really important 'millennial' questions of growing global inequality, alternatives to capitalism and women's empowerment (Antrobus, 2003; Eyben, 2006)."

Despite these early critiques, the commitment of states and the broader UN system during this early phase was crucial for establishing the MDGs as the dominant narrative for both international development and global health. OECD states ensured this by recalibrating and aligning their financial support and leveraging their structural institutional, productive power across the UN system. For example, the US Government launched two major funding initiatives, the President's Emergency Plan for AIDS Relief (PEPFAR) and the President's Malaria Initiative (PMI); these initiatives combined with the Global Fund and GAVI to help boost development assistance for health in 2000 from $\$ 11.6$ billion to $\$ 33.1$ billion in 2012 (Murray, 2015). The MDGs were also supported by the creation of two new public-private partnership institutions, GAVI for immunizations and the Global Fund to Fight HIV, TB and Malaria, to accelerate progress and provide financial resources to reinforce the MDGs' productive power (Hanefeld, 2014; Storeng, 2014).

\section{Phase Two 2005-2010: Consolidation and Critique}

In 2005 UN Member States met for the World Summit at the UN in New York. With strong leadership from the UN Secretariat, the United Kingdom and other developed states, the Summit outcome document approved by national leaders continually referenced the MDGs and encouraged states to 'adopt, by 2006, and implement comprehensive national development strategies to achieve the internationally agreed development goals and objectives, including the Millennium Development Goals' (United Nations, 2005). In fact, states endorsed and requested the UN system to support the development of MDG-based 
national development strategies and Poverty Reduction Strategy Papers at the country level (Pizarro, 2013). The UK also made the MDGs a centerpiece of their hosting the G8 Summit in Gleneagles in 2005. This deepened and expanded the productive and institutional power of the MDG agenda amplifying this power within the UN and international system.

Following this Summit and the G8 meetings, more UN and international institutions became involved in national reporting and the regularity of this reporting increased. A review of twenty-two Poverty Reduction Strategy Papers-fifteen of which were prepared between 2005 and 2007 and one in 2008 - highlighted that almost all of them expressed a commitment to the MDGs(Fukuda-Parr, 2010). These initiatives spurred other actions. For example, Malawi in 2006 started publishing an annual MDGs report (Waage et al., 2010). ${ }^{2}$ Commitment to the MDGs continued to grow as states like the United Kingdom, and others like Japan, continued to advance the MDG approach as a way to consolidate, align and amplify their development investments. In 2008, governments, foundations, businesses and civil society groups met at the United Nations Headquarters in New York for another high-level event. More than $\$ 16$ billion was committed to accelerate progress exerting some compulsory power using the appeal of financial assistance to support states towards the MDGs (United Nations, 2008).

While support for the MDGs during this period expanded, critique of the MDG approach also grew. The rise of many emerging economies, particularly in the wake of the 2008 economic crisis, began to create additional space to question the MDG approach. States like Indonesia used their experiences with the MDGs to criticize and improve the process, but also to raise their own profile. Experts noted tendencies to focus on targets which were comparatively easier to implement or monitor (some have called this the tyranny of averages) which led to variable progress and had adverse implications for equity. Critics called for improvements in national averages ignoring the inverse care law with implications for equity (Gwatkin, 2005). Despite raising valid concerns, critique also indirectly reinforced the existing productive power of the MDGs.

During this period, the Global Fund and other so-called global health initiatives (GHIs), like the US' PEPFAR program, provided incredible amounts of resources and prioritized attention for HIV/AIDS, a MDG. In fact, the energy, innovation and attention from HIV/AIDS has led some to even argue that HIV/AIDS invented global health (Brandt, 2013). Some defined global health as 'an area for study, research, and practice that places a priority on improving health and achieving equity in health for all people worldwide' (Koplan et al., 2009). Others argued that global health was simply "a foreign policy instrument of hyperrich nations"(Horton, 2014). But more realistically, global health was, as one academic argued, 'more a bunch of problems than a discipline' (Kleinman, 2010). The problems of global health in this period were predominantly the 'vertical' MDG health issues of child and maternal mortality and HIV/AIDS, TB and Malaria.

One MDG critic argued that, "the MDG phenomenon carries the potential for distorting meaningful intellectual and research agendas, and could function as the catalyst and vehicle for a fundamental realignment of the political economy of development at the global level" (Saith, 2006). This was accurate for global health. Experts noted that the MDGs were distorting priorities and spending and would not be achievable without broader, more 'horizontal' investments in national health systems (Travis et al., 2004).

\footnotetext{
2 Eventually by 2013, the UNDP counted more than 400 national MDG reports.
} 
To consider this, the World Health Organization, with financial support from Italy and strong engagement from many states receiving funding from GHIs, which were funding the MDGs, convened a collaborative research effort and a high-level dialogue called Maximizing Positive Synergies in 2009. The research consortium convened identified areas for concern, and concluded more attention should be devoted to strengthening health systems which could also encourage better alignment and integration between GHIs and health systems (World Health Organization Maximizing Positive Synergies Collaborative Group et al., 2009). One synthesis analysis found positive effects of the MDG approach as, "a rapid scale-up in HIV/AIDS service delivery, greater stakeholder participation, and channeling of funds to non-governmental stakeholders, mainly NGOs and faith-based bodies" and negative effects as 'distortion of recipient countries' national policies, notably through distracting governments from coordinated efforts to strengthen health systems and re-verticalization of planning, management and monitoring and evaluation systems" (Biesma et al., 2009).

\section{Phase Three 2010-2015: Accelerated Implementation and the Final Push}

This phase started with the 2010 MDG Review Summit. The MDGs' strong productive power was institutionalized throughout the UN and international system, and implementation efforts continued. Despite additional pledges of more than $\$ 40$ billion to accelerate progress, the Summit concluded that progress in many countries was 'patchy' and 'uneven' (United Nations, 2010). Focus shifted thereafter to a MDG Acceleration Framework (MAF) to support lagging countries to achieve the MDGs in the remaining five years. While discussions began to consider the end of the MDGs, UN policymakers focused on accelerating progress towards implementation accompanied by additional reviews and analyses as well as a proliferation of case studies profiling national best practices and innovations.

For example, the London International Development Centre and the Lancet collaborated on an in-depth Commission reviewing progress in 2010 (Waage et al., 2010). While heralding the remarkable success of the MDGs for agenda setting, the Commission noted particular missed opportunities for synergies between efforts across education, health and gender sectors. A lack of strong ownership by national institutions also created challenges. The Commission also highlighted that MDGs disregarded and fragmented health systems (Travis et al., 2004), ignored changing demographics as well as overlooked emerging health challenges such as non-communicable diseases (Alleyne et al., 2013), mental health or road traffic injuries.

Other analyses showed mixed evidence on how the MDGs affected national policymaking. In one survey of 118 countries, eighty-six percent reported that they acted in response to the MDGs (United Nations Development Group, 2005). Another review of national development plans in fifty countries showed that thirty-two countries either adapted or localized the MDGs into national planning (Seyedsayamdost, 2014). But low and middle-income countries could simply be referencing the MDGs in their national development plans to satisfy donor or international 'norms' of MDG political correctness (Fukuda-Parr, 2008). Indeed, one review suggested that states had two distinct motivations for engaging with the MDGs: first, to increase their global visibility and influence (this was usually more reflective of middle-income or emerging countries); and second, to receive increases in overseas development assistance (ODA) (Sarwar, 2015). In the first case, it could be that emerging economies recognized the power of the MDGs, and wanted to use this MDG platform to amplify their own power; and in the second case, this reflects some countries' 
need for financing and thus be able to be "coerced" by the MDGs. Yet even when countries integrated MDGs into their policy and planning processes, this did not necessarily lead to MDG issues being domestically prioritized or provided with the necessary domestic funding. Again, it could be that countries were reacting to the productive, institutional and structural power of the MDGs by integrating them into their policy processes.

While the UN system was determined to prioritize the MDGs, discussions began during this phase to consider what would come after the MDGs. Some states, like the United Kingdom, were in favor of continuing the MDGs beyond 2015. Other states like Colombia argued for the creation of new SDGs which would focus more on broader issues including the environment, and be universally applicable for all countries. In fact, many states, particularly middle-income states, wanted to broaden the MDGs to be universally relevant for all countries. Starting in 2012 in the wake of the Rio+20 conference, an elaborate UN-led, multi-stakeholder, multi-sectoral process began discussions around a process to create a successor framework for the post-2015 era. The ensuing policy process was arguably the most inclusive and consultative in United Nations in history, and the extraordinary engagement and commitment reflected the MDGs' tremendous power.

While there were countless consultations and opportunities to provide input between 2012-14, UN Member States ensured they had the final decision in the process designing it to conclude with intergovernmental negotiations between 2014 and 2015 which would give the final approval for the post-2015 agenda. These state negotiations were profoundly political and heavily disputed. This reflected emerging economies recognition of the influence of the MDGs and the opportunity to exert their own institutional and productive power through shaping the conceptualization of the new agenda. Leveraging their respective structural and productive power within the UN system, for example, Brazil's hosting of the Rio+20 Forum in 2012, emerging economies shifted and reframed the discussion on the post-2015 agenda from MDGs to SDGs to reflect more closely their own national interests broadening the MDGs to a wider and more holistic development agenda. But what are the implications of these three phases of experience with the MDGs for the SDGs, and the future of global health?

\section{Section Three: Implications for the SDGs and the future of global health}

Before considering the implications, it is useful to summarize and review how states engaged and exerted power. In the first phase, developed states held considerable strength in all forms of power. They were not only able to create and determine the agenda, but they were also able to use their financial and human resources leveraging both their position and networks as compulsory, structural and institutional power within the international system to ensure other states accepted and adopted their policy guidance. Developed states were also willing to sacrifice some of their control when working with the Bretton Woods institutions, the UN and other states, they rebranded and reframed their IDGs into MDGs to gain greater legitimacy.

In the second phase, building on early academic critics and their initial experiences, emerging economies began simultaneously to question the MDG approach more forcefully, and engage with the MDGs within the UN system; they also recognized and responded to the increased focus on global health. On the one hand, this deepened and reinforced the productive power of the MDG paradigm, but on the other hand, it also showcased the rising 
and burgeoning structural power of emerging economies to begin to contribute to and shape the field of global health. This was part of a broader geopolitical shift of power globally as well as within the still nascent field of global health which began to shift away from a heavily 'verticalized' approach in the early 2000s to a broader, more horizontal approach (Bärnighausen et al, 2011).

The third phase exemplified the productive power of institutionalizing the MDGs as the dominant paradigm for global development. There was tremendous interest and engagement in what would come after the MDGs, how the post-2015 agenda would be determined and what would be part of it illustrated the productive power of the MDGs. In this phase, the ability and success of developed states to ensure the continuation of the MDG paradigm within the beginning of a new SDG approach reinforced the original MDG approach; however, it also signaled emerging economies' rising institutional and structural power as they were able to negotiate for a broadening of the goals to be a more universal agenda relevant for every country. The SDG agenda essentially incorporates the MDGs and expands this agenda to include new goals related to environmental sustainability, labor and governance. In other words, developed states were able to maintain their focus on MDGs and institutionalize them within the SDGs, but the emerging economies were also able to broaden the MDGs into the SDGs.

But what does this mean for the broader SDGs and the development agenda, as well as for the more specific global health agenda? What does the MDG experience mean for the future of the SDG agenda? Given the MDG-established policy processes, the SDGs could likely continue to be as relevant and dominant for the international development agenda as the MDGs were. However, in the same way that not all of the MDGs received the same levels of attention and commitment (and some of the MDG goals and their indicators were contested and eventually revised in the early stages, eg as explained earlier on reproductive health), this is also likely to happen and is already happening within the SDGs. For example, during the UN's July 2017 High Level Political Forum (HLPF) on SDGs focused on reviewing select thematic goals (1-no poverty; 2-zero hunger; 3-good health and well-being; 5-gender equality; 9-industry, innovation and infrastructure; 14-life below water; and 17partnerships for the goals). At the HPLF, countries reported in voluntary national reviews (VNRs), some countries also only selectively reported on goals meaning that they "cherrypicked" which goals to report on and which to ignore in their reporting. Instead of implementing them in whole as they were designed, it is possible and likely that states will determine an informal ranking of the SDGs through their financial investments and policy priorities as also happened with the MDGs.

A more pressing question, however, regards the role of the SDGs for global health: what will the SDGs mean for global health? Will the SDGs be as central and formative for the future of global health as the MDGs were? In other words, will the SDGs matter for global health as much as or more than the MDGs did, especially as low and middle-income states engaged in the process to conceptualize them? Or will the future of global health better be debated and defined elsewhere? Given the centrality of health to the MDGs (3/8 Goals) compared to the SDGs (1/17), it seems unlikely that health will remain as central to the sustainable development agenda, and thus, unlikely that the SDGs will remain as central to the future of the global health agenda. But the interpretation of Goal 3 on health for the future of global health continues to be contested. 
The recently directly-elected-by-states Director-General of the World Health Organization (WHO), is clearly in favor of a focus on the SDGs with a slight shift in the interpretation of SDG 3 on health as he stated in July 2017 at the High Level Political Forum: "I regard universal health coverage as WHO's top priority. [...] Universal health coverage is included in the Sustainable Development Agenda. Indeed, it is the centrepiece of the Sustainable Development Goal health targets" (Tedros, 2017). However, two recently established global health initiatives, one the Coalition for Epidemic Preparedness Innovations (CEPI) started with $\$ 460$ million from the governments of Germany, Japan and Norway, plus the Bill \& Melinda Gates Foundation and the Wellcome Trust, and another "Resolve" focused on heart disease and stroke as well as disease outbreaks started with \$225 million dollars from Bloomberg Philanthropies, the Chan Zuckerberg Initiative, and the Bill and Melinda Gates Foundation, make little reference to the Sustainable Development Goals in their mission statements or aims. These new funding mechanisms could be rebranded or co-opted by the UN system at a later stage; however, for now, they seem to indicate a potential move away from the SDGs as the leitmotiv of global health. This being said, it has been acknowledged that the SDGs imply a dramatic paradigm shift within global health (Buse \& Hawkes, 2015), and it could be that this transition is still ongoing. Apropos there are already some efforts to reconceptualize global health as planetary health more in line with sustainable development and the SDG agenda (Whitmee et al., 2015). Regardless of the relationship with the SDGs, the exact future shape, direction and priorities of global health are continuing to evolve, and remain to be seen.

\section{Conclusion}

This analysis demonstrates the value of using power as a framework to understand and assess actors', particularly states, roles in global health. Better understanding how power is exerted and deployed could help improve how actors engage, and identify key determinants of comparatively more 'successful' or 'effective' efforts in global health; a deeper knowledge of what determines better policy efforts could also enhance policy processes and lead to better governance mechanisms (Marten, 2014). This could transform states' abilities to negotiate global health policies ultimately improving and saving lives. It might also mean other actors increase their attempts to leverage states' influence.

This analysis and the transition from the MDGs to the SDGs also has implications for how power is exerted at the UN and shapes the development and global health agenda. Compulsory power has become less relevant over time (as development assistance became less critical), the exertion of structural and institutional power are becoming more contested (as emerging economies begin to demand some restructuring of the system) and productive power is becoming perhaps the most important and relevant form of power, especially for global health. In between 2000-2015, developed states started by dominating the policy process, but by the end, emerging economy states were able to contest the previously unchecked structural and institutional power of developed states. They contested the agenda in the negotiation of the post-2015 agenda and thus, the future exertion of productive power. But what does this mean for future policy making efforts, and what are the implications of this analysis? 
First, the experience of the MDGs showcases the potential for states to leverage structural and institutional power to exert productive power for policymaking within the UN system. Given the geopolitical changes in the last decade, this could mean negotiations where states can exert institutional and productive power will now become more contested, and potentially gridlocked resulting in broad or watered-down agreements. The contestation of the SDGs could represent this. The negotiated process lasted around three years and produced 17 goals and 169 indicators. If this is the case, it is possible that the UN's productive power could become challenged, or less important. It could be that states could position new or alternative actors to the UN, which are better aligned to their interests, to create productive power, and seek new policy fora in which they might be better positioned to exert institutional and structural power. Alternatively, it could be that this greater contestation, even with eventual compromise, could lead to more committed national buy-in and engagement for new policies and processes. The SDGs could be a litmus test for helping to understand and assess the productive power and influence of UN policymaking.

In the case of creating and institutionalizing the MDGs, states exerting institutional and structural power seemed to work best in alliances with other states as well as non-state actors. Even comparatively less structurally or institutionally powerful states belong to one grouping or another within the UN system, eg the African Union or the G-77, which offers states increased possibilities for exerting some institutional or structural power within the UN system. This empowers states to leverage these relationships and abilities to engage on and create new mechanisms which have the potential to exert productive power. The MDGs created new norms around international development and global health exerting tremendous productive power. States played a critical role in creating and shaping this productive power, and this story could offer insights to other states seeking to leverage national power to create or institutionalize new norms in global health policymaking through the United Nations. One potential lesson based on this experience could be that states do not need to make huge financial investments to exert compulsory power, but rather need to consider how wield institutional, structural and productive power more effectively and strategically.

Second, this analysis illustrates the enduring importance and centrality of state engagement in global health policymaking. Without states, the MDGs and SDGs would not exist, or would look substantially different. While there is understandable excitement and interest in the role of new non-state actor engagement, the role of states within global health remains underappreciated (Ricci, 2009) and overlooked (Marten \& Smith, 2017). Since 2000, the role of states in determining and managing health has changed and evolved. Globalization increased transnational actors' abilities to shape and challenge how states spend, raise and allocate resources for health (Smith \& Hanson, 2011). Despite being responsible for health, states continue to see challenges to their prior monopoly over health governance and regulation (Walt, 1998). The MDGs themselves reflect some of these tensions. At one level, the MDGs are a challenge to states' authority to manage and determine their own health priorities. The MDGs were largely crafted by developed states for low- and middle-income states. At another level, they reflect states' continued authority as all states endorsed the MDGs at the General Assembly and ultimately participated in rethinking and reframing the MDGs into SDGs. Some of these challenges to states are state-sponsored or state-endorsed as states defer some level of sovereignty empowering international institutions or non-state actors to challenge their sovereignty. Despite continuing changes in 
their roles and challenges to their authority, states remain the predominant and decisive actors in global health policymaking.

Third, the example of the MDGs also highlights the importance of legitimacy for policymaking in global health. While developed states likely could have continued with their IDGs at the turn of the century, they recognized the value of legitimacy in transitioning them through the Bretton Woods institutions and reframing them within the UN policy process in negotiation with other states, thus trading some level of control for greater legitimacy. As part of this, the United Nations, a state-based institution, is generally perceived to be the most legitimate forum for establishing and determining health policies and priorities. The question now is will this legitimacy still be valued highly enough to justify the likely increases in political contestation. In other words, will states, recognizing the potential limits to their institutional and structural power at the UN, now seek to exert productive power in other policy fora like the G-7 or the G-20? Until now, the United Nations as a policy forum and the MDGs as a UN mechanism played an integral part in contributing to define and shape the field of global health. While it is clear that states will continue to be critical actors shaping the field of global health, the role of SDGs in defining the future of global health is, for now, unclear.

\section{Acknowledgements:}

The author would like to thank Johanna Hanefeld and Richard Smith for excellent feedback and support as well as two anonymous reviewers for incise feedback and helpful comments on drafts of this paper.

\section{References:}

AbouZahr, C., \& Boerma, T. (2010). Five years to go and counting: progress towards the Millennium Development Goals. Bulletin of the World Health Organization, 88(5), 324. https://doi.org/10.2471/BLT.10.078451

Alleyne, G., Binagwaho, A., Haines, A., Jahan, S., Nugent, R., Rojhani, A., \& Stuckler, D. (2013).

Embedding non-communicable diseases in the post-2015 development agenda. The Lancet, 381(9866), 566-574. https://doi.org/10.1016/S0140-6736(12)61806-6

Antrobus, P. (2005). Critiquing the MDGs from a Caribbean Perspective. Gender and Development, 13(1), 94-104.

Bachrach, P., \& Baratz, M. S. (1962). Two Faces of Power. The American Political Science Review, 56(4), 947-952. https://doi.org/10.2307/1952796 
Baldwin, D. A. (2016). Power and International Relations: A Conceptual Approach. Princeton, New Jersey: Princeton University Press.

Barnett, M., \& Duvall, R. (Eds.). (2005a). Power in Global Governance. Cambridge, UK ; New York: Cambridge University Press.

Barnett, M., \& Duvall, R. (2005b). Power in International Politics. International Organization, 59(1), 3975.

Bärnighausen, T., Bloom, D. E., \& Humair, S. (2011). Going Horizontal - Shifts in Funding of Global Health Interventions. New England Journal of Medicine, 364(23), 2181-2183. https://doi.org/10.1056/NEJMp1014255

Biesma, R. G., Brugha, R., Harmer, A., Walsh, A., Spicer, N., \& Walt, G. (2009). The effects of global health initiatives on country health systems: a review of the evidence from HIV/AIDS control. Health Policy and Planning, 24(4), 239-252. https://doi.org/10.1093/heapol/czp025

Birn, A.-E. (2014). Philanthrocapitalism, past and present: The Rockefeller Foundation, the Gates Foundation, and the setting(s) of the international/global health agenda. Hypothesis Journal, 12(1). Retrieved from http://www.hypothesisjournal.com/?p=2503

Brandt, A. M. (2013). How AIDS Invented Global Health. New England Journal of Medicine, 368(23), 2149-2152. https://doi.org/10.1056/NEJMp1305297

Brinkerhoff, J., Smith, S., \& Teegen, H. (Eds.). (2007). NGOs and the Millennium Development Goals. Palgrave Macmillan US. Retrieved from http://www.palgrave.com/la/book/9781403979742

Brown, T. M., Cueto, M., \& Fee, E. (2006). The World Health Organization and the Transition From "International" to "Global" Public Health. American Journal of Public Health, 96(1), 62-72. https://doi.org/10.2105/AJPH.2004.050831

Buse, K., \& Hawkes, S. (2014). Health post-2015: evidence and power. The Lancet, 383(9918), 678-679. https://doi.org/10.1016/S0140-6736(13)61945-5 
Buse, K., \& Hawkes, S. (2015). Health in the sustainable development goals: ready for a paradigm shift? Globalization and Health, 11, 13. https://doi.org/10.1186/s12992-015-0098-8

Díaz-Martínez, E., \& Gibbons, E. D. (2014). The Questionable Power of the Millennium Development Goal to Reduce Child Mortality. Journal of Human Development and Capabilities, 15(2-3), 203217. https://doi.org/10.1080/19452829.2013.864621

Dieleman, J. L., Schneider, M. T., Haakenstad, A., Singh, L., Sadat, N., Birger, M., ... Murray, C. J. L. (2016). Development assistance for health: past trends, associations, and the future of international financial flows for health. Lancet (London, England), 387(10037), 2536-2544. https://doi.org/10.1016/S0140-6736(16)30168-4

Dieleman, Joseph, Murray, Christopher, \& Haakenstad, Annie. (2015). Financing Global Health 2014: Shifts in Funding as the MDG Era Closes. Retrieved from http://www.healthdata.org/policyreport/financing-global-health-2014-shifts-funding-mdg-era-closes

Easterly, W. (2008). How the Millennium Development Goals Are Unfair to Africa. World Development, $37(1), 26-35$.

Erasmus, E., \& Gilson, L. (2008). How to start thinking about investigating power in the organizational settings of policy implementation. Health Policy and Planning, 23(5), 361-368. https://doi.org/10.1093/heapol/czn021

Fehling, M., Nelson, B. D., \& Venkatapuram, S. (2013). Limitations of the Millennium Development Goals: a literature review. Global Public Health, 8(10), 1109-1122. https://doi.org/10.1080/17441692.2013.845676

Frenk, J., Gómez-Dantés, O., \& Moon, S. (2014). From sovereignty to solidarity: a renewed concept of global health for an era of complex interdependence. The Lancet, 383(9911), 94-97. https://doi.org/10.1016/S0140-6736(13)62561-1 
Fried, L. P., Bentley, M. E., Buekens, P., Burke, D. S., Frenk, J. J., Klag, M. J., \& Spencer, H. C. (2010).

Global health is public health. The Lancet, 375(9714), 535-537. https://doi.org/10.1016/S0140$6736(10) 60203-6$

Fukuda-Parr, S. (2008). Are the MDGs Priority in Development Strategies and Aid Programmes? Only few are! (Working Paper No. 48). International Policy Centre for Inclusive Growth. Retrieved from https://ideas.repec.org/p/ipc/wpaper/48.html

Fukuda-Parr, S. (2010). Reducing Inequality - The Missing MDG: A Content Review of PRSPs and Bilateral Donor Policy Statements. IDS Bulletin, 41(1), 26-35. https://doi.org/10.1111/j.1759$5436.2010 .00100 . x$

Fukuda-Parr, S., \& Hulme, D. (2011). International Norm Dynamics and the "End of Poverty": Understanding the Millennium Development Goals. Global Governance: A Review of Multilateralism and International Organizations, 17(1), 17-36. https://doi.org/10.5555/ggov.2011.17.1.17

Fukuda-Parr, S., Yamin, A. E., \& Greenstein, J. (2014). The Power of Numbers: A Critical Review of Millennium Development Goal Targets for Human Development and Human Rights. Journal of Human Development and Capabilities, 15(2-3), 105-117.

https://doi.org/10.1080/19452829.2013.864622

Gilpin, R. (1975). U. S. Power and the Multinational Corporation: The Political Economy of Foreign Direct Investment. Basic Books.

Gilpin, R. (1983). War and Change in World Politics (Revised ed. edition). Cambridge: Cambridge University Press.

Gwatkin, D. R. (2005). How much would poor people gain from faster progress towards the Millennium Development Goals for health? The Lancet, 365(9461), 813-817. https://doi.org/10.1016/S0140-6736(05)17992-6 
Hanefeld, J. (2014). The Global Fund to Fight AIDS, Tuberculosis and Malaria: 10 years on. Clinical Medicine (London, England), 14(1), 54-57. https://doi.org/10.7861/clinmedicine.14-1-54

Horton, R. (2014). Offline: The case against global health. The Lancet, 383(9930), 1705.

https://doi.org/10.1016/S0140-6736(14)60797-2

Hulme, D. (2007). The Making of the Millennium Development Goals: Human Development Meets Results-Based Management in an Imperfect World (SSRN Scholarly Paper No. ID 1246696). Rochester, NY: Social Science Research Network. Retrieved from https://papers.ssrn.com/abstract=1246696

Hulme, D. (2009). The Millennium Development Goals (MDGs): A Short History of the World's Biggest Promise (SSRN Scholarly Paper No. ID 1544271). Rochester, NY: Social Science Research Network. Retrieved from http://papers.ssrn.com/abstract=1544271

Hulme, D. (2010). Reproductive Health and the Millennium Development Goals: Politics, Ethics, Evidence and an "Unholy Alliance" (SSRN Scholarly Paper No. ID 1545907). Rochester, NY: Social Science Research Network. Retrieved from https://papers.ssrn.com/abstract=1545907

Kleinman, A. (2010). Four social theories for global health. The Lancet, 375(9725), 1518-1519. https://doi.org/10.1016/S0140-6736(10)60646-0

Koplan, J. P., Bond, T. C., Merson, M. H., Reddy, K. S., Rodriguez, M. H., Sewankambo, N. K., \& Wasserheit, J. N. (2009). Towards a common definition of global health. The Lancet, 373(9679), 1993-1995. https://doi.org/10.1016/S0140-6736(09)60332-9

Lee, K., Chagas, L. C., \& Novotny, T. E. (2010). Brazil and the Framework Convention on Tobacco Control: Global Health Diplomacy as Soft Power. PLoS Med, 7(4), e1000232. https://doi.org/10.1371/journal.pmed.1000232

Lukes, Steven. (2004). Power: A Radical View. Palgrave. Retrieved from http://https://he.palgrave.com/page/detail/?sf1=barcode\&st1=9780333420911 
Marten, R. (2015). Global Health Warning: Definitions Wield Power. International Journal of Health Policy and Management, 5(3), 207-209. https://doi.org/10.15171/ijhpm.2015.213

Marten, R., \& Smith, R. D. (2017). State Support: A Prerequisite for Global Health Network Effectiveness; Comment on "Four Challenges that Global Health Networks Face." International Journal of Health Policy and Management, O(0). Retrieved from http://www.ijhpm.com/article_3394.html

Marten, Robert, Hanefeld, Johanna, \& Smith, Richard. (2014). Power: The nexus of global health diplomacy? Journal of Health Diplomacy. Retrieved from http://www.ghdnet.org/sites/default/files/marten\%20hanefeld\%20smith_power\%20(1).pdf

McArthur, John. (2013, February 21). Own the Goals: What the Millennium Development Goals Have Accomplished. Retrieved April 9, 2017, from https://www.brookings.edu/articles/own-thegoals-what-the-millennium-development-goals-have-accomplished/

McArthur, John. (2014). The Origins of the Millennium Development Goals. SAIS Review, XXXIV(2), 5-24.

McCoy, D., Kembhavi, G., Patel, J., \& Luintel, A. (2009). The Bill \& Melinda Gates Foundation's grantmaking programme for global health. The Lancet, 373(9675), 1645-1653. https://doi.org/10.1016/S0140-6736(09)60571-7

McDougall, L. (2016). Discourse, ideas and power in global health policy networks: political attention for maternal and child health in the millennium development goal era. Globalization and Health, 12(1), 21. https://doi.org/10.1186/s12992-016-0157-9

McInnes, C., \& Lee, K. (2012). Global Health and International Relations (1 edition). Cambridge, UK ; Malden, MA: Polity.

Miskimmon, A., O'Loughlin, B., \& Roselle, L. (2017). Forging the World: Strategic Narratives and International Relations. Ann Arbor: University of Michigan Press.

Murray, C. J. L. (2015). Shifting to Sustainable Development Goals - Implications for Global Health. New England Journal of Medicine, 373(15), 1390-1393. https://doi.org/10.1056/NEJMp1510082 
Nossel, S. (2004, March 1). Smart Power. Foreign Affairs, (March/April 2004). Retrieved from https://www.foreignaffairs.com/articles/united-states/2004-03-01/smart-power

Ooms, G., Van Damme, W., Baker, B. K., Zeitz, P., \& Schrecker, T. (2008). The "diagonal" approach to Global Fund financing: a cure for the broader malaise of health systems? Globalization and Health, 4, 6. https://doi.org/10.1186/1744-8603-4-6

Piot, P. (2013). No Time to Lose: A Life in Pursuit of Deadly Viruses (1 edition). W. W. Norton \& Company.

Pizarro, Gonzalo. (2013). Lessons from the Operationalization of the MDGs (UNDP Working Paper No. 10). UNDP.

Ricci, J. (2009). Global health governance and the state: Premature claims of a post-international framework. Global Health, 3(1).

Saith, A. (2006). From Universal Values to Millennium Development Goals: Lost in Translation. Development and Change, 37(6), 1167-1199. https://doi.org/10.1111/j.1467-7660.2006.00518.x Samin, A. (2006). The Millennium Development Goals: A Critique from the South. Monthly Review, 57(10 (March)). Retrieved from https://monthlyreview.org/2006/03/01/the-millennium-developmentgoals-a-critique-from-the-south/

Sarwar, Moizza Binat. (2015). National MDG implementation: lessons for the SDG era (Working and Discussion Paper). Retrieved from https://www.odi.org/publications/10106-mdg-sdg-nationalpolicy-priority-lessons

Seyedsayamdost, Elham. (2014). MDG-based National Planning: An Assessment (Unpublished Report commissioned by UNDP Independent Evaluation Office).

Shearer, J. C., Abelson, J., Kouyaté, B., Lavis, J. N., \& Walt, G. (2016). Why do policies change? Institutions, interests, ideas and networks in three cases of policy reform. Health Policy and Planning, 31(9), 1200-1211. https://doi.org/10.1093/heapol/czw052 
Shiffman, J. (2008). Has donor prioritization of HIV/AIDS displaced aid for other health issues? Health Policy and Planning, 23(2), 95-100. https://doi.org/10.1093/heapol/czm045

Shiffman, J. (2014). Retrieved from http://papers.ssrn.com/abstract=2522789

Shiffman, J. (2016). Networks and global health governance: Introductory editorial for Health Policy and Planning supplement on the Emergence and Effectiveness of Global Health Networks. Health Policy and Planning, 31 Suppl 1, i1-2. https://doi.org/10.1093/heapol/czw019

Smith, R. D., \& Hanson, K. (Eds.). (2011). Health Systems in Low- and Middle-Income Countries: An economic and policy perspective. Oxford University Press. Retrieved from http://www.oxfordscholarship.com/view/10.1093/acprof:oso/9780199566761.001.0001/acprof $-9780199566761$

Storeng, K. T. (2014). The GAVI Alliance and the "Gates approach" to health system strengthening. Global Public Health, 9(8), 865-879. https://doi.org/10.1080/17441692.2014.940362

Travis, P., Bennett, S., Haines, A., Pang, T., Bhutta, Z., Hyder, A. A., ... Evans, T. (2004). Overcoming health-systems constraints to achieve the Millennium Development Goals. The Lancet, 364(9437), 900-906. https://doi.org/10.1016/S0140-6736(04)16987-0

UN Millennium Project. (2005). Investing in Development: A Practical Plan to Achieve the Millennium Development Goals. New York: United Nations Development Programme.

UN Secretary-General. (2001). Road map towards the implementation of the United Nations Millennium Declaration Report of the Secretary-General (Fifty-sixth session, Item 40 of the provisional agenda, Follow-up to the outcome of the Millennium Summit). UN General Assembly. Retrieved from http://www.un.org/documents/ga/docs/56/a56326.pdf

United Nations. (2005). 2005 World Health Summit Outcome. Retrieved from http://www.who.int/hiv/universalaccess2010/worldsummit.pdf 
United Nations. (2010). Millennium Summit Outcome Document. Keeping the promise: united to achieve the Millennium Development Goals. Retrieved from http://www.un.org/en/mdg/summit2010/pdf/mdg\%20outcome\%20document.pdf

United Nations. (2015). The Millennium Development Goals Report, 2015. New York.

United Nations Development Group. (2005). Making the MDGs Matter: A Country Perspective (Report of a UNDG Survey). United Nations Development Group.

van Olmen, J., Marchal, B., Van Damme, W., Kegels, G., \& Hill, P. S. (2012). Health systems frameworks in their political context: framing divergent agendas. BMC Public Health, 12, 774. https://doi.org/10.1186/1471-2458-12-774

Waage, J., Banerji, R., Campbell, O., Chirwa, E., Collender, G., Dieltiens, V., ... Unterhalter, E. (2010). The Millennium Development Goals: a cross-sectoral analysis and principles for goal setting after 2015. The Lancet, 376(9745), 991-1023. https://doi.org/10.1016/S0140-6736(10)61196-8

Walt, G. (1998). Globalisation of international health. The Lancet, 351(9100), 434-437. https://doi.org/10.1016/S0140-6736(97)05546-3

Whitmee, S., Haines, A., Beyrer, C., Boltz, F., Capon, A. G., Dias, B. F. de S., ... Yach, D. (2015). Safeguarding human health in the Anthropocene epoch: report of The Rockefeller FoundationLancet Commission on planetary health. The Lancet, 386(10007), 1973-2028. https://doi.org/10.1016/S0140-6736(15)60901-1

Wilkinson, R., \& Hulme, D. (Eds.). (2012). The Millennium Development Goals and Beyond: Global Development after 2015 (1 edition). London ; New York: Routledge.

World Health Organization Maximizing Positive Synergies Collaborative Group, Samb, B., Evans, T., Dybul, M., Atun, R., Moatti, J.-P., ... Etienne, C. (2009). An assessment of interactions between global health initiatives and country health systems. Lancet (London, England), 373(9681), 21372169. https://doi.org/10.1016/S0140-6736(09)60919-3 
